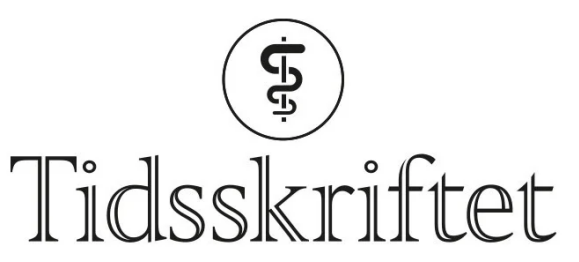

DEN NORSKE LEGEFORENING

\title{
Omskjæring hos kvinner bosatt i Norge - konsekvenser og behandling
}

ORIGINALARTIKKEL

\section{SøLVI TARALDSEN}

solvi.taraldsen@yahoo.com

Nasjonalt senter for kvinnehelseforskning

Kvinneklinikken

Oslo universitetssykehus, Rikshospitalet

og

Institutt for klinisk medisin

Universitetet i Oslo

Hun har bidratt med utforming av studien, innsamling av data, analyse samt utarbeiding og revisjon av manus.

Sølvi Taraldsen er spesialist i fødselshjelp og kvinnesykdommer, tidligere stipendiat ved Nasjonalt senter for kvinnehelseforskning og er assisterende fylkeslege i Oslo og Viken.

Forfatteren har fylt ut ICMJE-skjemaet og oppgir ingen interessekonflikter.

\section{KATRINE M. OWE}

Nasjonalt senter for kvinnehelseforskning

Kvinneklinikken

Oslo universitetssykehus, Rikshospitalet

Hun har bidratt med analyse av data og revisjon av manus.

Katrine M. Owe er forsker ved Nasjonalt senter for kvinnehelseforskning.

Forfatteren har fylt ut ICMJE-skjemaet og oppgir ingen interessekonflikter.

\section{ANNE SEJERSTED BØDTKER}

Kvinneklinikken

Drammen sykehus

Hun har bidratt med innsamling av data og revisjon av manus.

Anne Sejersted Bødtker er spesialist i fødselshjelp og kvinnesykdommer og tidligere overlege.

Forfatteren har fylt ut ICMJE-skjemaet og oppgir ingen interessekonflikter.

\section{IDA WAAGSBØ BJØRNTVEDT}

Kvinneklinikken

Sørlandet sykehus Kristiansand

Hun har bidratt med innsamling av data og revisjon av manus.

Ida Waagsbø Bjørntvedt er spesialist i fødselshjelp og kvinnesykdommer og overlege.

Forfatteren har fylt ut ICMJE-skjemaet og oppgir ingen interessekonflikter.

\section{BIRGITTE MIDHAUG EIDE}

Kvinneklinikken

Stavanger universitetssjukehus 
Hun har bidratt med innsamling av data og revisjon av manus.

Birgitte Midhaug Eide er lege i spesialisering.

Forfatteren har fylt ut ICMJE-skjemaet og oppgir ingen interessekonflikter.

\section{MARIT SANDBERG}

Kvinneklinikken

Haukeland universitetssjukehus

og

Universitetet i Bergen

Hun har bidratt med innsamling av data og revisjon av manus.

Marit Sandberg er lege i spesialisering i fødselshjelp og kvinnesykdommer og stipendiat.

Forfatteren har fylt ut ICMJE-skjemaet og oppgir ingen interessekonflikter.

\section{CECILIE THERESE HAGEMANN}

Kvinneklinikken

St. Olavs hospital

og

Institutt for klinisk og molekylær medisin

NTNU

Hun har bidratt med innsamling av data samt utarbeiding og revisjon av manus.

Cecilie Therese Hagemann er spesialist i fødselshjelp og kvinnesykdommer, overlege og

førsteamanuensis.

Forfatteren har fylt ut ICMJE-skjemaet og oppgir følgende interessekonflikter: Hun har mottatt forelesningshonorar fra Kirkens Bymisjon og Den Oromiske Kvinneforening.

\section{$P \AA L \varnothing \mid A N$}

Kvinneklinikken

Universitetssykehuset Nord-Norge, Troms $\emptyset$

Han har bidratt med utforming av studien, innsamling av data og revisjon av manus.

Pål Øian er spesialist i fødselshjelp og kvinnesykdommer, professor emeritus og tidligere overlege.

Forfatteren har fylt ut ICMJE-skjemaet og oppgir ingen interessekonflikter.

\section{SIRI VANGEN}

Nasjonalt senter for kvinnehelseforskning

Kvinneklinikken

Oslo universitetssykehus

og

Institutt for klinisk medisin

Universitetet i Oslo

Hun har bidratt med idé, utforming av studien, analyse og revisjon av manus.

Siri Vangen er spesialist i fødselshjelp og kvinnesykdommer, leder ved Nasjonalt senter for

kvinnehelseforskning og professor 2.

Forfatteren har fylt ut ICMJE-skjemaet og oppgir ingen interessekonflikter.

\section{INGVIL KRARUP SØRBYE}

Nasjonalt senter for kvinnehelseforskning

Kvinneklinikken

og

Fødeavdelingen

Oslo universitetssykehus, Rikshospitalet

Hun har bidratt med utforming, datainnhenting, analyse, utarbeiding og revisjon av manus.

Ingvil Krarup Sørbye er spesialist i fødselshjelp og kvinnesykdommer og overlege.

Forfatteren har fylt ut ICMJE-skjemaet og oppgir ingen interessekonflikter.

\section{BAKGRUNN}

Poliklinikktilbud for kvinner som har gjennomgått omskjæring finnes ved syv norske sykehus. I vår studie presenteres symptomer, funn og behandling hos kvinner som ble undersøkt ved poliklinikkene i perioden 2004-15. 
Hvert sykehus identifiserte pasienter ved søk etter relevante diagnose- og behandlingskoder. Alle som hadde vært til undersøkelse ved poliklinikkene, ble inkludert. Data ble innhentet fra journaler.

\section{RESULTATER}

913 kvinner ble inkludert. Median alder ved omskjæring var syv år og ved konsultasjon 26 år. Nær halvparten var gravide. De fleste (81\%) hadde type 3-omskjæring (infibulering). Av disse hadde $87 \%$ gynekologiske plager. Blant kvinner med omskjæring type 1 og type 2 rapporterte henholdsvis $55 \%$ og 70 \% gynekologiske plager. I alt $64 \%$ fikk kirurgisk behandling, hovedsakelig deinfibulering ( $98 \%)$. Det var registrert få komplikasjoner etter deinfibulering.

\section{FORTOLKNING}

Hos mange yngre og ikke-gravide infibulerte kvinner kan omskjæringsrelaterte plager som kan behandles med deinfibulering, ha vært til stede fra barne- og ungdomsalder. Det finnes trolig et udekket behandlingsbehov blant omskårne kvinner, uavhengig av omskjæringstype.

\section{HOVEDFUNN}

Nær halvparten av kvinnene var gravide og median alder var 26 år.

Fire av fem hadde omskjæring type 3 .

Ved alle typer kvinnelig omskjæring var urogenitale plager hyppig rapportert (55-87\%).

Som oftest var behandlingen deinfibulering, som ga få komplikasjoner.

På verdensbasis har mer enn 200 millioner kvinner og jenter gjennomgått kvinnelig omskjæring (11). Praksisen følger etniske skillelinjer og er primært forankret i kultur, ikke religion (므). Den omfatter inngrep av ulikt omfang og klassifiseres i tre hovedtyper (figur 1) (3). Terminologien er omdiskutert (2). Begrepet female genital mutilation (kjønnslemlestelse) ble innført for å markere forskjell fra omskjæring av gutter. Det formidler imidlertid også fordømmelse. I denne artikkelen om behandling har vi valgt å bruke kvinnelig omskjcering, som er bedre egnet enn kjønnslemlestelse i klinisk kommunikasjon.

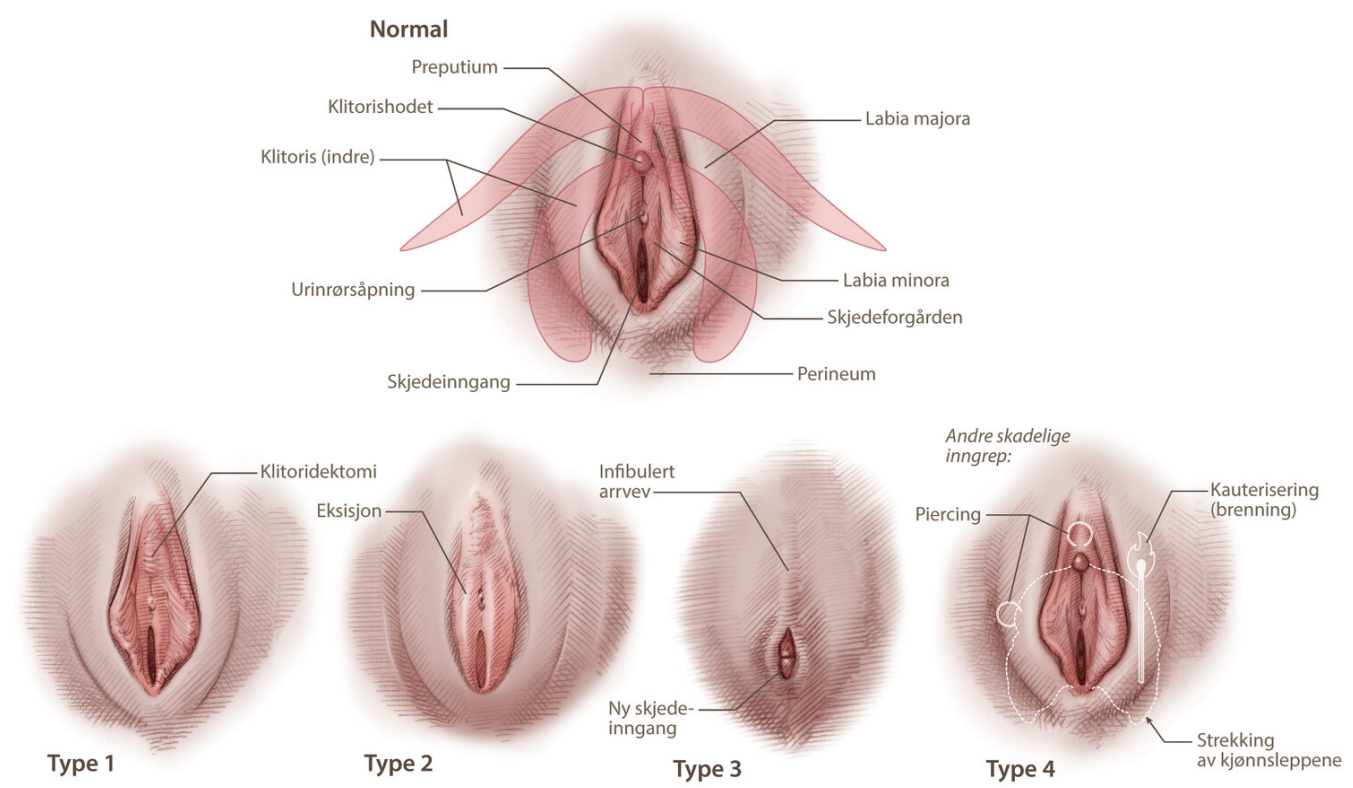

Figur 1 Typer kvinnelig omskjæring, basert på WHOs definisjoner (2). a) Type 1: Helt eller delvis fjerning av eksterne del av klitoris. b) Type 2: Helt eller delvis fjerning av eksterne del 
av klitoris og labia minora, med eller uten labia majora. c) Type 3: Innsnevring av vaginalåpningen med dannelse av et dekkende seil ved at labia minora eller majora eksideres og gror sammen, med eller uten fjerning av eksterne del av klitoris (infibulering). d) Type 4: Alle andre skadelige prosedyrer i genitalia.

Type 1- og 2-omskjæring er mest utbredt, men enkelte land har stor forekomst av type 3 (infibulering) (2). I Norge var det bosatt ca. 17300 omskårne jenter eller kvinner i 2013 (4). Av disse var halvparten innvandret fra Somalia, der type 3 dominerer (2, 4 .).

Kvinnelig omskjæring er knyttet til underlivsplager og kan ha konsekvenser for seksuell og psykisk helse og for fødsel (5-7.). Forskningsbasert kunnskap er imidlertid mangelfull, både når det gjelder helsekonsekvenser og behandling $(\underline{8}$, .9.). Kvinner som har gjennomgått omskjæring, er mer utsatt for urinveisinfeksjon, bakteriell vaginose og smertefullt samleie enn kvinner uten omskjæring (7.). For komplikasjoner som menstruasjonssmerter, utflod og kløe, seksuelt overførbare sykdommer, infertilitet, vaginal obstruksjon og cystedannelse mangler det kunnskapsgrunnlag (7.). Omskårne kvinner rapporterer oftere redusert seksuell lyst og tilfredshet sammenliknet med ikke-omskårne, mens for psykologiske konsekvenser er kunnskapsgrunnlaget usikkert (므).

I metaanalyser har man konkludert med at det samlet sett er $\emptyset \mathrm{kt} \mathrm{risiko} \mathrm{for} \mathrm{uheldige}$ fødselsutfall hos omskårne kvinner (5). Noen studier har rapportert at risikoen øker proporsjonalt fra type 1 - til type 3 -omskjæring $(5, \underline{10})$. Det er ikke klart i hvilken grad funn fra studier i afrikanske land kan overføres til høyinntektsland (1ㅡ).

I en systematisk kunnskapsoppsummering av utfall av kirurgisk behandling for omskjæringsrelaterte problemer identifiserte man studier om deinfibulering, cystekirurgi og klitorisrekonstruksjon, og fant lite evidens rundt effekt av behandlingen (프).

I samarbeid med Sosial- og helsedirektoratet etablerte seks kvinneklinikker i 2004 poliklinikker for behandling av kvinnelig omskjæring. Hensikten var å bedre helsehjelpen i alle helseregioner ved å bygge kompetanse og samle erfaring, gjøre det enkelt for andre helsetjenester å henvise og konferere samt å gi et tilbud til kvinner som kontaktet sykehusene. Det ble gjennomført et felles kompetansebyggingsprogram og etablert et fagnettverk som utviklet kliniske retningslinjer og fastsatte felles bruk av diagnose- og prosedyrekoder (13). Syv sykehus har nå slike tilbud. I denne studien rapporteres helseplager, funn og behandling hos kvinner som var til undersøkelse ved poliklinikkene i perioden 2004-15.

\section{Materiale og metode}

Alle sykehus med poliklinikktilbud for omskårne kvinner deltok i studien: Drammen sykehus, Haukeland universitetssjukehus, Oslo universitetssykehus, Stavanger universitetssjukehus, St. Olavs hospital, Sørlandet sykehus Kristiansand og Universitetssykehuset Nord-Norge, Troms $\emptyset$. Hvert sykehus identifiserte alle kvinner som hadde fått en relevant diagnose- eller behandlingskode som var i bruk ved poliklinikkene i perioden 2004-15. Pasienter med både norsk etternavn og fornavn ble ekskludert, mens øvrige journaler ble vurdert. Vi inkluderte alle som hadde vært til unders $ø$ kelse for en omskjæringsrelatert problemstilling ved poliklinikken. Lege, jordmor eller medisinstudent innhentet data fra medisinsk journal, inkludert fødejournalsystemer.

Vi registrerte sosiodemografiske opplysninger om omskjæringen, gynekologisk anamnese og funn, henvising og behandling. Omskjæringen ble kategorisert som type 1, 2 eller 3 eller ukjent type.

Deskriptiv statistikk ble benyttet, og resultatene ble utforsket med krysstabeller. Data ble analysert i SPSS versjon 26 (IBM Corp., Amonk, NY).

En brukerrepresentant fra det norsk-somaliske miljøet deltok i prosjektgruppen. 
Studien er godkjent av Regional etisk komité og gitt fritak fra krav om samtykke (2015/433 REK sør-øst D).

\section{Resultater}

I alt 913 kvinner ble inkludert, hvorav 676 (74\%) var født i Somalia, 91 (10\%) i Eritrea og 41 (5\%) i Etiopia (tabell 1). Median alder ved første konsultasjon var 26 år (interkvartilområde (IQR) 8). Totalt 419 (46\%) var gravide, og andelen varierte fra $31 \%$ til $47 \%$ mellom sykehusene. Øvrige demografiske opplysninger, inkludert botid i Norge, sivilstatus og språkkunnskaper er gjengitt i tabell 1.

\section{Tabell 1}

Omskjæringstype og bakgrunnsopplysninger hos kvinner som ble undersøkt på poliklinikkene $(\mathrm{N}=913)$

\begin{tabular}{|c|c|c|}
\hline & Antall & Prosent \\
\hline \multicolumn{3}{|l|}{ Omskjæringstype } \\
\hline Type 1 & 67 & 7,3 \\
\hline Type 2 & 69 & 7,6 \\
\hline Type 3 & 743 & 81,4 \\
\hline Ingen omskjæring & 22 & 2,4 \\
\hline Usikker type/ikke opplyst & 12 & 1,3 \\
\hline Median alder ved første konsultasjon (IQR) & $26(8)$ & \\
\hline \multicolumn{3}{|l|}{ Fødeland } \\
\hline Somalia & 676 & 74,0 \\
\hline Eritrea & 91 & 10,0 \\
\hline Etiopia & 41 & 4,5 \\
\hline Annet ${ }^{1} /$ ikke opplyst & 105 & 11,5 \\
\hline \multicolumn{3}{|l|}{ Sivilstatus $^{2}$} \\
\hline Gift/samboer & 475 & 62,2 \\
\hline Annet & 289 & 37,8 \\
\hline Gravid & 419 & 45,9 \\
\hline Hadde født barn & 180 & 19,7 \\
\hline Hadde ikke født barn & 733 & 80,3 \\
\hline \multicolumn{3}{|l|}{ Botid i Norge ${ }^{3}$} \\
\hline$<2$ år & 196 & 21,5 \\
\hline 2-10 år & 328 & 35,9 \\
\hline$>10$ år & 125 & 13,7 \\
\hline
\end{tabular}




\begin{tabular}{|lcr|}
\hline & Antall & \multicolumn{2}{c|}{ Prosent } \\
\hline Snakket norsk & 498 & 58,6 \\
\hline Gjorde seg forstått på annet språk & 68 & 8,0 \\
\hline Snakket ikke norsk & 284 & 33,4 \\
\hline Tolk under konsultasjonen & 198 & \\
\hline Familiemedlem/venn tolket & 53 & \\
\hline Ingen opplysninger om tolk & 33 \\
\hline
\end{tabular}

${ }^{1}$ Nigeria, Gambia, Sierra Leone

${ }^{2}$ Manglende opplysninger 16,3\%

${ }^{3}$ Manglende opplysninger 28,9\%

${ }^{4}$ Manglende opplysninger 6,9\%

I alt 559 (61\%) var henvist fra primærhelsetjenesten, mens 164 (19\%) tok kontakt uten henvisning. 426 (47\%) av kvinnene var unders $\varnothing \mathrm{kt}$ ved Oslo universitetssykehus.

Omskjæringstype 3 ble funnet hos 743 kvinner ( $81 \%)$, mens 67 (7\%) hadde type 1 og 69 (8\%) type 2. Hos atten kvinner (2\%) ble det ikke funnet tegn til gjennomgått omskjæring. Median alder ved omskjæring var syv år ( $\mathrm{IQR} 3)$. Seks kvinner var blitt omskåret $\mathrm{i}$ hjemlandet etter innvandring til Norge. Blant infibulerte kvinner hadde 126 (17\%) gjennomgått deinfibulering eller annen korreksjon, hvorav 26 (21\%) i Norge. Blant de 126 kvinnene var det $45(36 \%)$ som hadde gjennomgått reinfbulering. Ingen hadde gjennomgått dette i Norge.

Figur 2 viser årsaker til henvisning og kontakt etter omskjæringstype. Blant infibulerte kvinner var gynekologiske plager årsaken hos 372 (36\%), mens henvisnings- eller kontaktårsak var vurdering av omskjæring hos 31 (46\%) blant dem med type 1 og $32(45 \%)$ blant dem med type 2.

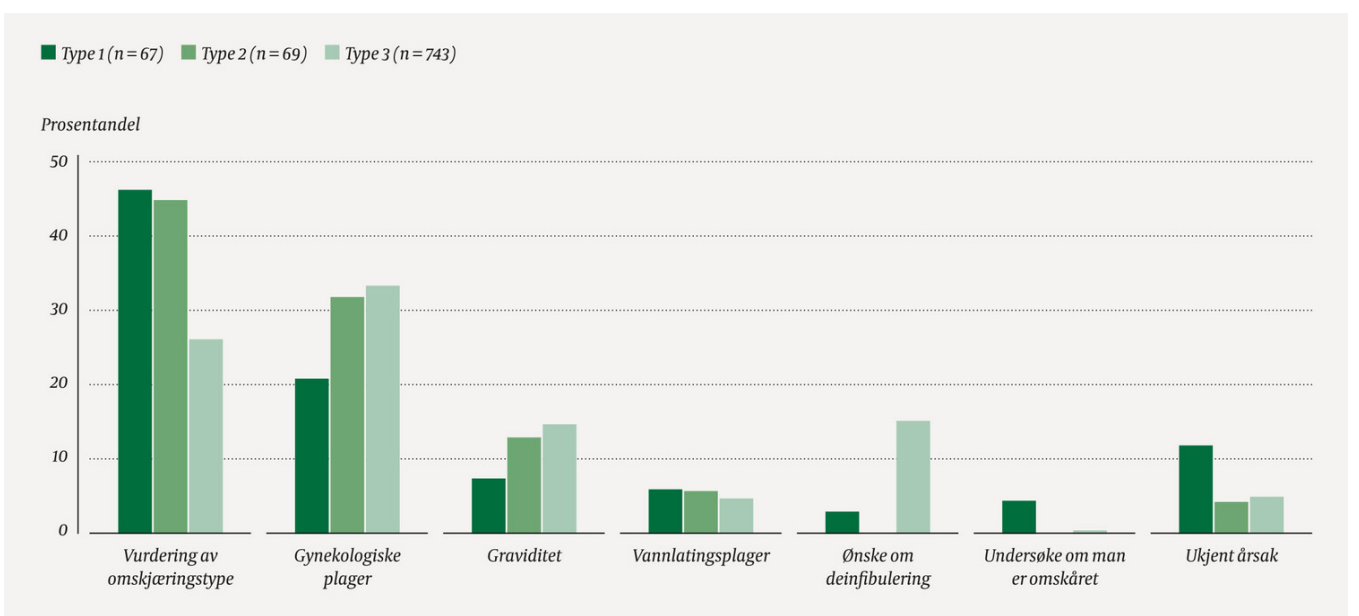

Figur 2 Henvisnings- eller kontaktårsak hos undersøkte kvinner etter omskjæringstype (N $=879$ ).

Figur 3 viser gynekologiske plager etter omskjæringstype. Smerter ble rapportert i alle grupper. Blant kvinner med type 3-omskjæring rapporterte 210 (28\%) vanskelig eller smertefullt samleie og 161 (22\%) langvarig eller smertefull vannlatning. Blant kvinner med type 2 rapporterte henholdsvis $16(23 \%)$ og 8 (12\%) det samme. Seks kvinner med type 3 hadde retinert menstruasjonsblødning. 


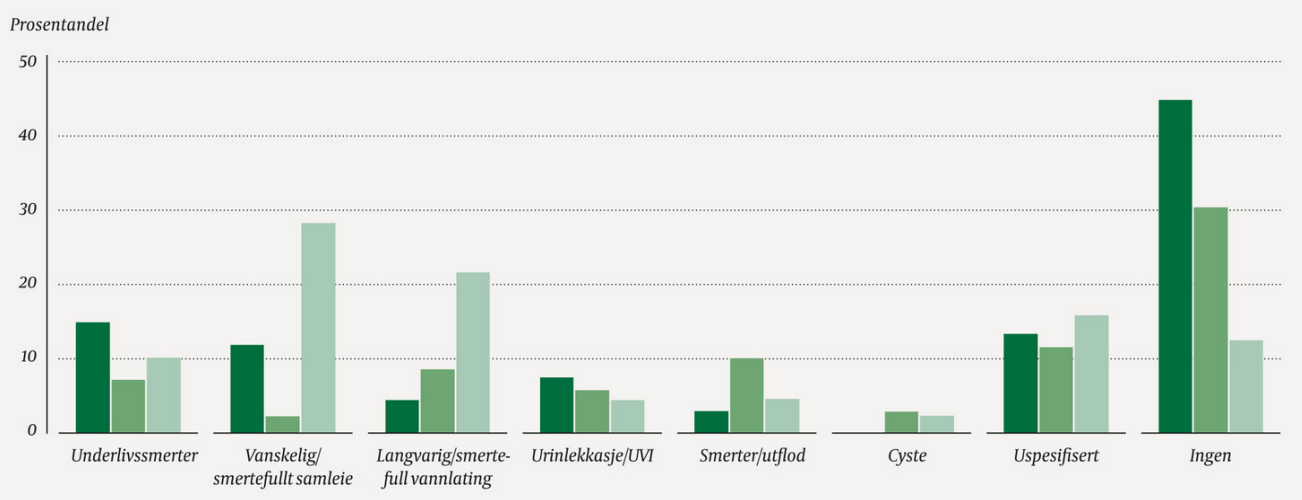

Figur 3 Antall registrerte urogenitale plager hos undersøkte kvinner etter omskjæringstype $(\mathrm{N}=879) . \mathrm{UVI}=$ gjentatte urinveisinfeksjoner.

Vaginalåpningens størrelse var angitt til under $1 \mathrm{~cm}$ hos 124 (17\%) kvinner med type 3omskjæring og 1-4 cm hos 382 ( $51 \%$ ), mens klitoris var beskrevet som uaffisert hos 172 (31\%). Blant dem med type 1- eller type 2-omskjæring var klitoris uaffisert hos 9(14\%) og 8 (14\%) kvinner (figur 4). Cyster i vulva ble funnet hos 44 kvinner. Gynekologisk unders $\varnothing$ kelse ble avbrutt hos elleve kvinner, fordi den var for smertefull eller belastende.

पype $1(n=67) \square$ Type $2(n=69) \square$ тyре $3(n=743)$

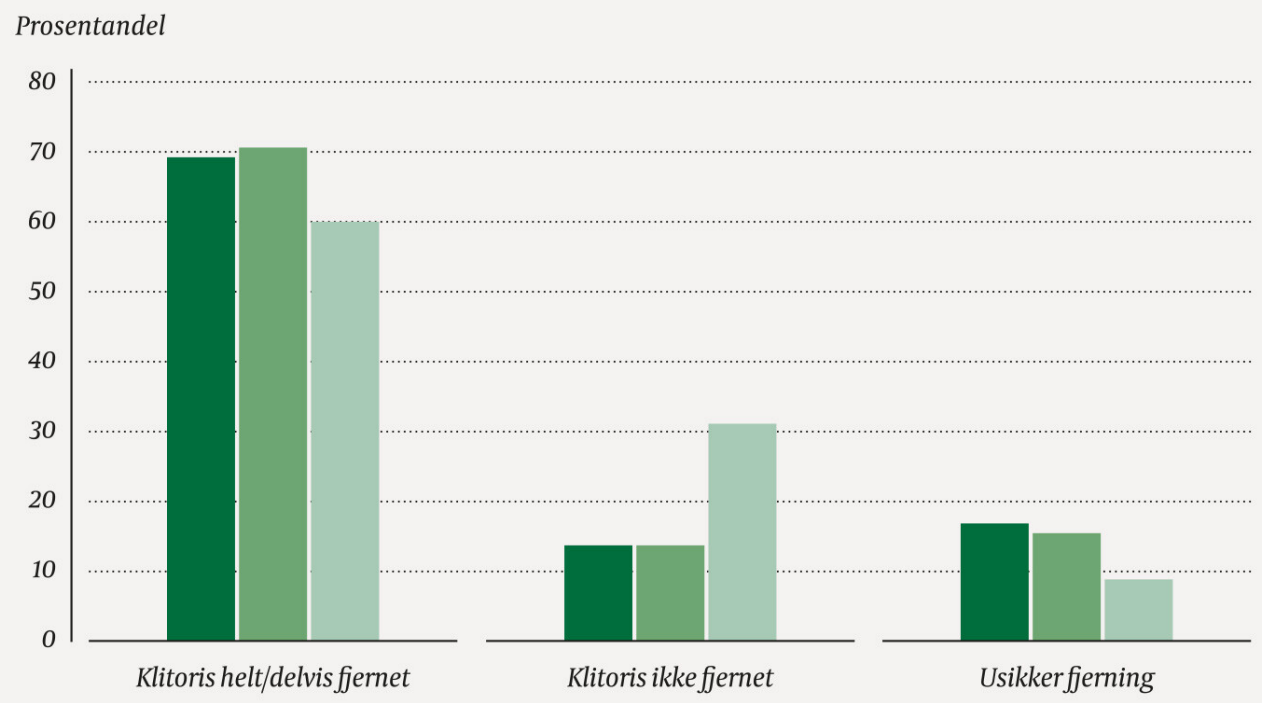

Figur 4 Forhold rundt klitoris etter omskjæringstype $(\mathrm{N}=879)$.

Av kvinnene med kjent omskjæringstype fikk 564 (64\%) kirurgisk behandling.

Deinfibulering ble gjort hos 530 ( $94 \%$ av disse, enten alene eller i kombinasjon med annet inngrep. Hos 348 (66\%) kvinner ble infibuleringen åpnet fram til klitoris og hos 150 (28\%) fram til uretralåpningen. Det ble planlagt åpning under fødsel hos $49(25 \%)$ av de gravide som var infibulert. Totalt 32 (6\%) kvinner fikk fjernet cyster.

Mens 404 (76\%) kvinner fikk behandling på poliklinikken i lokalbed øvelse, ble de øvrige behandlet dagkirurgisk. Andelen som ble behandlet på poliklinikken for deinfibulering eller annen omskjæringskorreksjon, varierte fra 4 (7\%) til 303 (94\%) mellom sykehusene. Totalt fikk 77 kvinner (15\%) utført deinfibulering i narkose, men tallene varierte fra 1 (5\%) til $26(46 \%)$. 
Rekontakt var dokumentert hos totalt 118 (21\%) kvinner, og blant disse hadde 20 (17\%) postoperative smerter, fem (4\%) rapporterte infeksjon, mens én kvinne hadde blødning og sårruptur.

\section{Diskusjon}

Mange kvinner hadde helseplager som kan behandles relativt enkelt og som kan ha vært til stede fra barne- eller ungdomsalder. Sett i lys av dette var medianalderen på 26 år høy. Sammen med en stor andel gravide som trolig var henvist i forbindelse med svangerskapskontroller, kan dette tyde på et udekket behov for behandling hos yngre og ikke-gravide kvinner. Dette er i overensstemmelse med kvalitative studier der man har rapportert manglende kjennskap til poliklinikktilbudene hos kvinner i brukergruppene

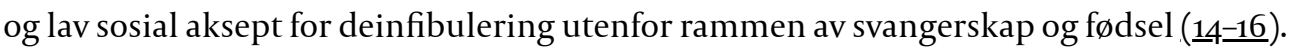

Andelen som kontaktet poliklinikken uten henvisning, var større blant ikke-gravide enn gravide. Dette kan reflektere at henvisningsinstansene er mindre bevisste på helseplager enn på problemstillinger knyttet til fødsel, og at kvinner i mindre grad oppsøker dem for urogenitale plager. Norske veiledere anbefaler at både gravide og ikke-gravide med kvinnelig omskjæring undersøkes og/eller henvises for å avklare omskjæringsstatus og behov for kirurgisk behandling (17.).

Det var stor variasjon i det anatomiske omfanget av type 3-omskjæring. Slik variasjon beskrives i Verdens helseorganisasjons (WHO) reviderte klassifikasjon, som ikke lenger legger til grunn at fjernet genitalvev øker fra type 1 til type $2 \operatorname{og}_{3}(3, \underline{18})$. Mens $17 \%$ av de infibulerte kvinnene hadde en vaginalåpning under $1 \mathrm{~cm}$, var klitoris beskrevet som uaffisert hos $31 \%$. I en studie er det rapportert at nesten halvparten hadde intakt klitoris under infibuleringsseilet (19.). Til sammenlikning var klitoris uaffisert hos $14 \%$ av dem med type 1 og type 2 i vårt materiale.

I tråd med tidligere studier rapporterte kvinner med type 3-omskjæring flere gynekologiske helseplager enn dem med type 1 eller type 2 (7.). Likevel hadde opptil halvparten av kvinnene med type 1 og type 2-omskjæring smerte, dyspareuni, vannlatingsplager og andre gynekologiske plager. Disse kvinnene har poliklinikkene ikke spesifikke behandlingstilbud til. Tilbud om psykoseksuell rådgivning til omskårne kvinner, slik WHOs retningslinjer anbefaler, mangler i Norge (9.).

Som forventet var deinfibulering den dominerende behandlingen. Åpning av infibuleringen er nødvendig for å reetablere vaginal funksjon, men det finnes lite evidens for effekt av deinfibulering på helseutfall (므). Det er funnet at risiko for keisersnitt og perinealrifter er lavere hos kvinner som var deinfibulert sammenliknet med dem som ikke ble det. Hvorvidt det har betydning om åpningsinngrepet gjøres før svangerskap, i svangerskapet eller under fødsel er uavklart $(9, \underline{12})$. En studie fant nylig at deinfibulering før eller under svangerskapet ikke beskyttet mot akutt keisersnitt hos somaliske

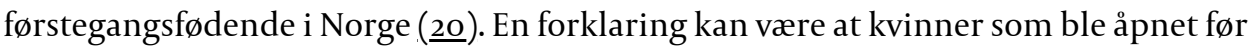
fødselsstart, hadde mer omfattende infibulering som innebar en persisterende risiko for keisersnitt. Alternativt, i tråd med hypotesen om at arrvev fra omskjæringen påvirker både fødselsprogresjon og perineum negativt (므), kan nytt arrvev fra deinfibuleringen tenkes å $\emptyset$ ke en slik effekt. I denne studien hadde somaliske førstegangsfødende større risiko for keisersnitt enn førstegangsfødende generelt, uavhengig av omskjæring.

Mange kvinner foretrekker deinfibulering under fødsel framfor i svangerskapet $(\underline{14}, \underline{\mathbf{2 1}})$. Norske veiledere anbefaler at man legger vekt på kvinnens ønsker. I vårt materiale ble imidlertid nær tre av fire gravide deinfibulert under svangerskapet. Infibuleringen ble åpnet fram til klitoris hos de fleste, i tråd med anbefalingen når kvinnen ikke er i fødsel (17.). Praksisforskjeller mellom sykehusene med hensyn til om deinfibulering ble utført i lokalbedøvelse, regional analgesi eller i narkose, tror vi skyldes sedvane. Det er ofte referert til at gynekologisk undersøkelse og behandling kan være spesielt smertefull og belastende 
hos omskårne kvinner, som kan gjenoppleve omskjæringssituasjonen. I vårt materiale var det kun $1 \%$ som fikk undersøkelsen avbrutt fordi den var smertefull eller psykisk

belastende.

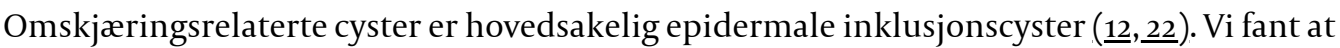
nesten halvparten av kvinnene med slike cyster ikke rapporterte om symptomer. De fleste

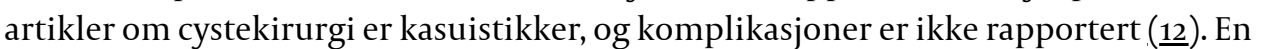
studie om klitorisrekonstruksjon inkluderte imidlertid en gruppe med kvinner som hadde klitoriale cyster og fikk utført cysteeksisjon samtidig. Disse kvinnene rapporterte redusert

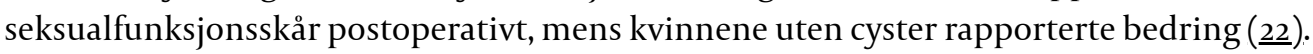
Det kan derfor være grunn til å utvise forsiktighet ved små asymptomatiske periklitoriale cyster.

Klitorisrekonstruksjon er så langt vi vet ikke utført i Norge, men tilbys i enkelte andre europeiske land, bl.a. Sverige (23). Det har særlig blitt utført hos kvinner med type 2omskjæring, og motivasjonen er gjenoppretting av identitet, bedre seksuell funksjon og mindre smerter (14.). De fleste er fornøyde, men opptil $20 \%$ har rapportert forverring av seksualfunksjon (12,14). Inngrepet er kontroversielt og er frarådet i Storbritannia og av Verdens helseorganisasjon inntil det er bedre dokumentert $(9,24)$.

I flere kvalitative studier er det rapportert svakheter ved behandlingstilbudet i Norge. Blant annet opplever kvinner mangelfull kunnskap blant helsepersonell, og et tilbud om psykoseksuell rådgivning mangler $(\underline{25}, \underline{26})$. De regionale poliklinikkene synes å fylle et behandlingsbehov. Et tilbud om psykoseksuell rådgivning kan knyttes til poliklinikkene, og de er en lett tilgjengelig ressurs for helsepersonell. Hvis klitorisrekonstruksjon skal tilbys, anbefaler vi at det gjøres som et tverrfaglig forskningsprosjekt i samarbeid med en eller flere av poliklinikkene.

Styrken ved vår studie er deskriptive data fra samtlige spesielle poliklinikktilbud. Blant svakhetene ved bruk av retrospektive journaldata er datakvalitet og manglende opplysninger. Utvalget gjør at funn ikke kan generaliseres til alle med kvinnelig omskjæring, og systematiske data om komplikasjoner mangler.

\section{KONKLUSJON}

Mange kvinner hadde plager som kan ha vært til stede fra barne- og ungdomsalder, og som kan behandles enkelt med deinfibulering. Terskelen for å henvise bør være lav. Leger bør være oppmerksomme på smerter og andre urogenitale plager hos jenter og kvinner som har gjennomgått omskjæring, uavhengig av omskjæringstype.

Takk til Ayyan Yasiin, Primcermedisinsk verksted i Kirkens Bymisjon for deltakelse i prosjektgruppen som representant for brukergruppen. Takk også til prosjektdeltakere som bidro med registrering av data: Ellen Røkkum og Ingrid Langen ved Oslo universitetssykehus, Signe Egenberg ved Stavanger universitetssjukehus og Risa Lonnee-Hoffmann, Silje Tvenge og Tone Aalberg Andersen ved St. Olavs hospital. Takk til R. Elise B. Johansen og Mai Mahgoub Ziyada ved Nasjonalt kompetansesenter om vold og traumatisk stress for bidrag $i$ den innledende fasen av prosjektet. Artikkelen er fagfellevurdert.

\section{LITTERATUR}

1. UNICEF. Female genital mutilation https://data.unicef.org/topic/child-protection/female-genitalmutilation/ Lest 20.6.2021.

2. UNICEF. Female Genital Mutilation/Cutting: A statistical overview and exploration of the dynamics of change. https://data.unicef.org/resources/fgm-statistical-overview-and-dynamics-of-change/ Lest 20.6.2021. 
3. World Health Organization. Eliminating female genital mutilation: An interagency statement. https://www.who.int/publications-detail/eliminating-female-genital-mutilation-an-interagencystatement Lest 28.9.2021.

4. DAMVAD. Utbredelse av kjønnslemlestelse i Norge. Oslo: Nasjonalt kunnskapssenter om vold og traumatisk stress, 2014. https://www.nkvts.no/content/uploads/2015/o8/utbredelse-avkjonnslemlestelse-i-norge.pdf Lest 28.9.2021.

5. Berg RC, Odgaard-Jensen J, Fretheim A et al. An updated systematic review and meta-analysis of the obstetric consequences of female genital mutilation/cutting. Obstet Gynecol Int 2014; 2014: 542859. [PubMed][CrossRef]

6. Berg RC, Denison E, Fretheim A. Psychological, Social and Sexual Consequences of Female Genital Mutilation/Cutting (FGM/C): A Systematic Review of Quantitative Studies. Oslo: Nasjonalt kunnskapssenter for helsetjenesten, 2010.

https://www.fhi.no/globalassets/dokumenterfiler/rapporter/2010/rapport_2010_13_fgmc_kjonnsleml estelse.pdf Lest 28.9.2021.

7. Berg RC, Underland V. Gynecological Consequences of Female Genital Mutilation/Cutting (FGM/C). Oslo: Nasjonalt kunnskapssenter for helsetjenesten, 2014.

8. Abdulcadir J, Rodriguez MI, Say L. Research gaps in the care of women with female genital mutilation: an analysis. BJOG 2015; 122: 294-303. [PubMed][CrossRef]

9. WHO Guidelines on the management of health complications from female genital mutilation. Geneve: World Health Organization, 2016. https://www.who.int/publications-detail/who-guidelineson-themanagement-of-healthcomplications-fromfemale-genital-mutilation Lest 19.3.2021.

10. Banks E, Meirik O, Farley T et al. Female genital mutilation and obstetric outcome: WHO collaborative prospective study in six African countries. Lancet 2006;367:1835-41. [PubMed] [CrossRef]

11. Minsart AF, N'guyen TS, Ali Hadji R et al. Maternal infibulation and obstetrical outcome in Djibouti. J Matern Fetal Neonatal Med 2015; 28:1741-6. [PubMed][CrossRef]

12. Berg RC, Taraldsen S, Said MA et al. The effectiveness of surgical interventions for women with FGM/C: a systematic review. BJOG 2018; 125: 278-87. [PubMed][CrossRef]

13. Veileder i generell gynekologi. Oslo: Norsk gynekologisk forening, 2004.

14. Berg RC, Taraldsen S, Said MA et al. Reasons for and Experiences With Surgical Interventions for Female Genital Mutilation/Cutting (FGM/C): A Systematic Review. J Sex Med 2017; 14: 977-90. [PubMed][CrossRef]

15. Johansen RE. Virility, pleasure and female genital mutilation/cutting. A qualitative study of perceptions and experiences of medicalized defibulation among Somali and Sudanese migrants in Norway. Reprod Health 2017; 14: 25. [PubMed][CrossRef]

16. Safari F. A qualitative study of women's lived experience after deinfibulation in the UK. Midwifery 2013; 29: 154-8. [PubMed][CrossRef]

17. Veilder i gynekologi. Oslo: Norsk gynekologisk forening, 2021.

https://www.legeforeningen.no/foreningsledd/fagmed/norsk-gynekologiskforening/veiledere/veileder-i-gynekologi/ Lest 28.9.2021.

18. Elmusharaf S, Elhadi N, Almroth L. Reliability of self reported form of female genital mutilation and WHO classification: cross sectional study. BMJ 2006; 333: 124-7. [PubMed][CrossRef]

19. Nour NM, Michels KB, Bryant AE. Defibulation to treat female genital cutting: effect on symptoms and sexual function. Obstet Gynecol 2006; 108: 55-6o. [PubMed][CrossRef]

20. Taraldsen S, Vangen S, Øian P et al. Female genital mutilation/cutting, timing of deinfibulation, and risk of cesarean section. Acta Obstet Gynecol Scand 2021; 100: 587-95. [PubMed][CrossRef]

21. Moxey JM, Jones LL. A qualitative study exploring how Somali women exposed to female genital mutilation experience and perceive antenatal and intrapartum care in England. BMJ Open 2016; 6: eoog846. [PubMed][CrossRef]

22. Thabet SMA, Thabet ASMA. Defective sexuality and female circumcision: the cause and the possible management. J Obstet Gynaecol Res 2003; 29: 12-9. [PubMed][CrossRef]

23. Sigurjonsson H, Jordal M. Addressing Female Genital Mutilation/Cutting (FGM/C) in the Era of Clitoral Reconstruction: Plastic Surgery. Curr Sex Health Rep 2018; 10: 50-6. [PubMed][CrossRef]

24. Royal College Obstetricians and Gynaecologists. Female Genital Mutialtion and its Management. https://www.rcog.org.uk/en/guidelines-research-services/guidelines/gtg53/ Lest 18.1.2020.

25. Ziyada MM, Lien IL, Johansen REB. Sexual norms and the intention to use healthcare services related to female genital cutting: A qualitative study among Somali and Sudanese women in Norway. PLoS One 2020; 15: e0233440. [PubMed][CrossRef] 
26. Mbanya VN, Terragni L, Gele AA et al. Barriers to access to the Norwegian healthcare system among sub-Saharan African immigrant women exposed to female genital cutting. PLoS One 2020;15: eo229770. [PubMed][CrossRef]

Publisert: 25. oktober 2021. Tidsskr Nor Legeforen. DOI: 10.4045/tidsskr.21.0509

Mottatt 29.6.2021, første revisjon innsendt 28.9.2021, godkjent 28.9.2021.

Publisert under åpen tilgang CC BY-ND. Lastet ned fra tidsskriftet.no 26. april 2023. 